\title{
PENGEMBANGAN MEDIA PERMAINAN MONAYA UNTUK MENINGKATKAN PEMAHAMAN MULTIKULTURAL PADA ANAK USIA 7-8 TAHUN
}

\author{
Melisa Indah Firdausi ${ }^{1}$, Hapidin $^{2}$, Tuti Tarwiyah ${ }^{3}$ \\ Universitas Negeri Jakarta
}

\begin{abstract}
The purpose of this study is to improve the multicultural understanding of children aged 7-8 years through the MONAYA game media. MONAYA's game media is a game of Cultural Monopoly which has content of cultural or multicultural diversity and has printed on large banners and makes children as pawns using dice and supporting cards of large size so as to attract children's interest in teaching and learning activities and become wrong an alternative learning media. This study uses ADDIE (Analyze, Design, Develop, Implement, Evaluate) methods and has been tested through one-on-one trials), small group trials and field group trials and has been validated by early childhood education experts, media experts and multicultural experts. The study has been held in East Jakarta for 2 months, on August and September, 2018. There is an increase in the results of very high child pre-test and post-test and enthusiastic activities which indicate that the MONAYA game media is suitable to be used to increase multicultural understanding of children aged 7-8 years.
\end{abstract}

Keyword: Games, Multicultural, Premiere Education

\begin{abstract}
Abstrak: Artikel ini merupakan hasil Penelitian dan Pengembangan (Research and Development) yang bertujuan untuk meningkatkan pemahaman multikultural anak usia 7 8 tahun melalui media permainan MONAYA (Monopoli Budaya). Media permainan MONAYA merupakan permainan Monopoli Budaya yang memiliki konten mengenai keberagaman budaya atau multikultural. Monopoli tersebut dicetak pada banner berukuran $2,5 \mathrm{~m} \times 3 \mathrm{~m}$ dan anak sebagai pion. Permainan didukung dengan dadu dan kartu-kartu pendukung dengan ukuran besar sehingga dapat menarik minat anak dalam kegiatan pembelajaran. Permainan ini menjadi salah satu alternatif media pembelajaran. Penelitian ini menggunakan metode ADDIE (Analyze, Design, Develop, Implement, Evaluate) dan telah diujicobakan melalui uji coba satu-satu (one to one), uji coba kelompok kecil (small group) dan uji coba kelompok besar (field group) serta telah divalidasi oleh pakar pendidikan anak usia dini, pakar media dan pakar multikultural. Ujicoba dilakukan di kota Jakarta Timur selama 2 bulan yaitu di bulan Agustus dan September 2018. Adanya peningkatan pada hasil kegiatan pre-test dan post-test dan antusias anak yang sangat tinggi yang menunjukkan bahwa media permainan MONAYA layak digunakan untuk meningkatkan pemahaman multikultural pada anak usia 7-8 tahun.
\end{abstract}

Kata Kunci: Permainan, Multikultural, Pendidikan Dasar

\section{PENDAHULUAN}

Indonesia merupakan negara kepulauan yang memiliki beraneka ragam kebudayaan di setiap daerahnya, mulai dari suku, bahasa daerah, adat istiadat, kepercayaan, kesenian daerah, dan budaya lainnya. Meskipun penuh dengan keragaman budaya, Indonesia tetap satu sesuai dengan semboyannya, "Bhinneka Tunggal Ika" yang memiliki arti "meskipun berbeda-beda, tetapi tetap satu jua". Artinya, perbedaan-perbedaan budaya di

'Universitas Negeri Jakarta, Email: melisa.firdausi国gmail.cam

${ }^{2}$ Universitas Negeri لakarta

${ }^{3}$ Universitas Negeri dakarta 
Indonesia tidak menjadikan Indonesia menjadi terpecah belah melainkan menjadi satu untuk lebih kuat. Selain itu, keragaman budaya ini pun dapat menjadi ciri khas Indonesia untuk diketahui secara global. Oleh karena itu, bangsa Indonesia dapat terus berupaya untuk melestarikan budaya agar tetap terjaga menjadi kebudayaan orisinil negara Indonesia.

Dewasa ini, kendala yang dimiliki bangsa Indonesia adalah masuknya budaya asing yang berkembang sangat pesat. Akibatnya, banyak pengaruh global yang tidak bisa direspon secara seimbang oleh masyarakat Indonesia, bahkan tidak jarang masyarakat Indonesia yang bangga terhadap kebudayaan yang dimiliki oleh bangsa lain. Oleh sebab itu, salah satu penanganan yang dapat dilakukan untuk mencegah terjadinya pengaruh dari budaya asing tersebut adalah dengan mengenal budaya Indonesia terlebih dahulu. Pengenalan budaya dapat ditanamkan sejak dini agar dapat menjadi penerus bangsa yang tidak kehilangan identitas bangsanya sendiri.

Terdapat penelitian yang dilakukan oleh Ekaterina yang mengenalkan budaya kepada anak dengan menggunakan beberapa aplikasi metode seperti bercerita tentang suatu negara, mengobrol langsung dengan anak mengenai negara tersebut, memperdengarkan lagu-lagu nasional dan memperlihatkan budayanya melalui kartun dapat membuat anak antusias dalam mengenal budaya dan memahaminya dengan lebih cepat (Mokeyevaa \& Andreeva, 2016, hlm. 2224). Penelitian lain yang dilakukan oleh Gita Widya, cara mengenalkan kebudayaan kepada anak adalah dengan mengunjungi museum sehingga anak tidak hanya dapat mengenal budaya dan adat istiadat saja tetapi mengenal sejarahnya juga (Soerjoatmodjo, 2015, hlm. 89). Hal tersebut menunjukkan bahwa dengan strategi dan metode pendekatan yang tepat dapat membuat anak tertarik untuk memahami apa yang terdapat pada tanah airnya sendiri.
Pengenalan budaya Indonesia kepada anak usia dini merupakan salah satu upaya pelestarian budaya seperti yang terdapat pada Peraturan Menteri Pendidikan dan Kebudayaan Republik Indonesia Nomor 10 Tahun 2014 tentang Pedoman Pelestarian Tradisi. Pelestarian Tradisi adalah upaya perlindungan, pengembangan dan pemanfaatan suatu kebiasaan dari kelompok masyarakat pendukung kebudayaan yang penyebaran dan pewarisannya berlangsung secara turun temurun (Peraturan Kemendikbud, 2014). Menurut Ramsey dalam Logvinova (2016, hlm. 207), sikap anak terhadap ras dan budayanya mulai tumbuh ketika usia prasekolah tepatnya di usia 3-4 tahun. Oleh karena itu, diperlukan suatu inovasi agar anak usia dini dapat mengenal budaya Indonesia sehingga meningkatkan pemahaman mereka akan budaya Indonesia.

Penelitian yang relevan terkait media yang digunakan dalam mengenalkan keragaman budaya pada anak adalah dengan menggunakan buku Pop-Up dengan judul "POBUNDO (Pop-Up Budaya Indonesia) sebagai Media Pembelajaran Berbasis Kebudayaan untuk Siswa Kelas IV Sekolah Dasar". Hasil dari penelitian ini menunjukkan bahwa kedua kelas mengalami kenaikan yang cukup signifikan antara pre-test dan setelah mendapat perlakuan sehingga media Pop-Up Budaya Indonesia adalah media pembelajaran berbasis kebudayaan yang layak, menarik dan efektif untuk mengenalkan kebudayaan Indonesia (Belva H, dkk., 2015, hlm. 65). Dengan media pembelajaran yang menarik dapat meningkatkan minat anak dalam belajar dan memahami kebudayaan Indonesia.

Studi pendahuluan telah dilakukan di 2 sekolah yang masing-masing sekolah memiliki 75 siswa dan 46 siswa. Kepala sekolah di salah satu tempat studi pendahuluan mengatakan bahwa anak kelas 1 SD baru mulai mengenal keberagaman yang ada di sekitar yaitu perbedaan agama, perbedaan suku dan perbedaan sifat teman 
sekelas. Lidiwinah Djawa selaku guru kelas SDN 13 Duren Sawit mengatakan bahwa media yang biasa digunakan untuk pemberian materi multikultural pada anak berupa media gambar, lagu dan audio visual. Sedangkan menurut Mardianah selaku guru kelas SDN 02 Duren Sawit mengatakan bahwa media yang selama ini digunakan dalam pembelajaran multikultural adalah media gambar dan buku cerita. Berdasarkan hasil wawancara tersebut, diketahui bahwa media permainan belum digunakan sebagai media pembelajaran multikultural pada anak di kedua sekolah.

Media permainan merupakan salah satu cara yang dapat menarik minat anak untuk meningkatkan pemahaman mengenai keberagaman budaya. Salah satu permainan yang cukup terkenal di dunia adalah permainan monopoli. Permainan monopoli merupakan permainan papan yang dilakukan menggunakan dadu dan peraturan tertentu yang bertujuan untuk menguasai semua petak. Seperti yang dikatakan oleh Casbergue dalam Mostowfi (2016, hlm. 5457) bahwa permainan papan merupakan alat edukasi yang dapat membantu anak untuk memperoleh keterampilan, mendapatkan informasi menenai pembelajaran, memperkuat pengetahuan dan meningkatkan kepercayaan. Selain itu, permainan papan juga dapat meningkatkan kerjasama dan solidaritas antar peserta. Hal tersebut menunjukkan bahwa jenis permainan papan, salah satunya permainan monopoli memiliki banyak manfaat untuk anak.

Berdasarkan penelitian-penelitian yang telah diuraikan sebelumnya dapat dipahami bahwa permainan dapat memberikan banyak manfaat bagi perkembangan anak usia dini diantaranya dapat mengembangkan potensi yang dimiliki anak dan juga meningkatkan pemahaman anak pada sesuatu hal yang baru. Penelitian yang dilakukan berbeda dengan penelitian sebelumnya yaitu pengembangan media permainan monopoli budaya. Penelitian ini berfokus pada pengembangan permainan monopoli yang berisi keragaman budaya nusantara yang dapat mengenalkan identitas individu pada anak seperti suku, ras, agama dan gender. Sasaran dari media permainan monopoli ini ialah anak usia 7-8 tahun atau kelas 1 SD.

Pendekatan yang digunakan dalam penelitian ini adalah menggunakan model ADDIE (Analyze, Design, Develop, Implement, and Evaluation). Model ADDIE dipilih karena model ADDIE memberikan arahan secara rinci mengenai langkah-langkah apa saja yang akan dilakukan selama penelitian pengembangan, mulai dari mencari sumber kesenjangan antara fakta lapangan dan keadaan yang sesuai harapan, membuat rancangan produk sampai biayanya, mengembangkan media hingga membuat buku petunjuk untuk guru dan murid, mempersiapkan guru dan murid untuk tahap implementasi hingga pemilihan alat evaluasi pun dibahas secara rinci.

Desain prosedural model ADDIE dari penelitian ini memiliki lima tahapan. Tahap pertama adalah Analyze, yaitu menganalisis kebutuhan berdasarkan kesenjangan yang ada. Kesenjangan yang dimaksud adalah gap antara fakta lapangan dengan harapan. Tahap kedua adalah Design, yaitu merancang semua biaya pembuatan media mulai dari proses hingga akhir dan juga rancangan desain pada produk. Tahap ketiga adalah Develop, yaitu mengembangkan media sesuai dengan tujuan pembelajaran. Pemilihan media yang baik dapat berpengaruh pada pencapaian akhir pembelajaran yang baik juga. Tahapan selanjutnya adalah Implement, yaitu mempersiapkan para guru dan para siswa untuk menggunakan media yang telah dibuat. Tahapan terakhir adalah Evaluate, yaitu melakukan evaluasi dengan cara melakukan pemilihan alat dan penyusunan kriteria evaluasi terlebih dahulu (Branch, 2008, hlm. 22).

Berdasarkan tahapan-tahapan tersebut, maka model ADDIE merupakan model yang tepat untuk digunakan sebagai panduan penelitian pengembangan media. 
Model penelitian dan pengembangan ini bertujuan untuk menhasikan suatu produk berupa media permainan MONAYA yang digunakan untuk meningkatkan pemahaman multikultural anak usia 7-8 tahun

Berdasarkan uraian di atas, peneliti terdorong untuk mengembangkan suatu bentuk media permainan. Permainan MONAYA (Monopoli Budaya) hadir sebagai alternatif untuk permasalahan anak agar dapat semakin mencintai Indonesia dengan mengenal keanekaragaman budayanya terlebih dahulu.

\section{METODOLOGI PENELITIAN}

Pada penelitian ini, metode yang digunakan adalah Research and Development $(\mathrm{RnD})$ atau penelitian dan pengembangan. Pada penerapannya, penelitian dan pengembangan ini menggunakan mix method (metode gabungan) antara metode kualitatif dan kuantitatif. Metode kualitatif berupa wawancara dan kuesioner sedangkan metode kuantitatif digunakan ketika mengolah data dengan menggunakan aplikasi SPSS dan rumus uji t berpasangan.

Penelitian dilakukan selama 2 bulan di 3 sekolah dengan kecamatan yang berbeda di Kota Jakarta Timur. Uji coba pertama adalah uji coba one to one yang berjumlah 5 orang yang bertempat di SDN Rawamangun 07 Pagi pada awal bulan Agustus 2018, selanjutnya uji coba yang kedua adalah uji coba small group yang berjumlah 10 orang di SDN Rawabunga 12 Pagi pada pertengahan bulan Agustus 2018 dan terakhir adalah uji coba field group yang berjumlah 32 orang di SDN Duren Sawit 13 Pagi di awal bulan September 2018. Instrumen yang digunakan ketika pengujian adalah instrumen soal pilihan ganda berjumlah 20 butir soal yang dikerjakan oleh anak kelas 1 SD dengan usia sekitar 7-8 tahun.

Setelah selesai penelitian di lapangan, dilakukan pengolahan data. Data berupa nilai pre-test dan post-test dari uji coba field group yang berjumlah 32 orang diolah menggunakan aplikasi SPSS versi 16 dengan rumus uji-t berpasangan untuk membandingkan nilai sebelum dan sesudah bermain MONAYA selama penelitian.

\section{HASIL PENELITIAN DAN PEMBAHASAN}

Penelitian pengembangan model dimulai dengan mengidentifikasi atau menganalisa kebutuhan dimana hasil dari analisa kebutuhan tersebut dapat digunakan untuk menciptakan atau mengembangkan model (baik produk maupun prosedur/proses) secara terencana, diuji di lapangan secara sistematis, dievaluasi, kemudian diperbaiki hingga pada akhirnya menjadi sebuah model yang memenuhi kriteria yang spesifik terkait efektivitas, kualitas atau standar lainnya, serta bermanfaat bagi penggunanya. Model yang dihasilkan dalam penelitian dan pengembangan ini berupa produk media permainan monopoli yang dinamakan MONAYA (Monopoli Budaya) yang dibuat dalam rangka untuk meningkatkan pemahaman multikultural berupa identitas individu (suku, ras, agama dan jenis kelamin) pada anak usia 7-8 tahun.

Media permainan MONAYA ini merupakan media berbentuk permainan monopoli yang diinovasi dengan menggunakan cetakan ukuran besar sebagai alat bantu penambah daya tarik, semangat dan motivasi belajar yang bertujuan agar materi yang disampaikan lebih mudah dipahami dan lebih terkesan. Konsep media ini dikembangkan berdasarkan budaya Indonesia dan teori-teori multikultural untuk anak usia dini sehingga media permainan yang dihasilkan sesuai dengan anak usia dini khususnya anak usia 7-8 tahun.

Dalam metode penelitian dan pengembangan, diperlukan validasi dari beberapa pakar seperti pakar pendidikan anak usia dini, pakar media dan pakar materi atau pakar multikultural. Selain itu, dibutuhkan juga uji coba mulai dari uji coba satu-satu (one to one), uji coba kelompok kecil (small group) dan uji coba kelompok 
besar (field group). Untuk mendapatkan validasi dari pakar, peneliti menyerahkan kuesioner kepada para pakar atau ahli yang telah disesuaikan dengan bidang masingmasing yang kemudian untuk diisi dan diberi saran maupun tanggapan terkait penelitian pengembangan ini. Berikut merupakan hasil penilaian dari pakar/ahli dalam rangka uji kelayakan media permainan MONAYA.

Tabel 1. N Hasil Penilaian Kelayakan Media oleh Pakar/Ahli

\begin{tabular}{cccc}
\hline No. & Pakar/Ahli & $\begin{array}{l}\text { Persentase } \\
\text { Kelayakan }\end{array}$ & Keterangan \\
\hline 1. & PAUD & $94,4 \%$ & $\begin{array}{l}\text { Sangat } \\
\text { Layak }\end{array}$ \\
\hline 2. & Multikultural & $100 \%$ & $\begin{array}{l}\text { Sangat } \\
\text { Layak }\end{array}$ \\
\hline 3. & Media & $100 \%$ & $\begin{array}{l}\text { Sangat } \\
\text { Layak }\end{array}$ \\
\hline
\end{tabular}

Berdasarkan hasil uji dari para pakar atau ahli di atas, maka media permainan MONAYA layak diujikan sebagai media untuk meningkatkan pemahaman multikultural anak usia 7-8 tahun di kota Jakarta Timur.

Selain uji teoritik, uji kelayakan selanjutnya didasarkan pula melalui uji empiris. Uji empiris dilakukan melalui uji coba satu-satu (one to one) dan uji coba kelompok kecil (small group). Uji empiris tersebut dilakukan dengan responden anak usia 7-8 tahun. Peneliti memperhatikan, mengamati dan mencatat respon dari responden dari uji coba media permainan MONAYA. Responden pada uji coba satusatu (one to one) berjumlah 5 orang dan responden pada uji coba kelompok kecil (small group) berjumlah 10 orang. Hasil pengamatan dari kedua uji coba tersebut menunjukkan respon yang positif, anakanak sangat antusias dan tertarik terhadap media permainan MONAYA.

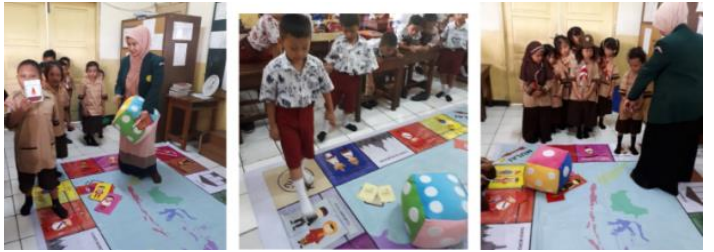

Gambar 1. Uji coba kelompok kecil (Small Group)

Setelah penilaian kelayakan media oleh pakar/ahli, peneliti melakukan uji coba field group atau uji coba kelompok besar yang berjumlah 32 responden yang kemudian memperoleh data pre-test dan post-test dengan hasil rata-rata nilai pre-test adalah sebesar 70,469, sedangkan rata-rata nilai post-test adalah sebesar 82,031. Selama uji lapangan tersebut, mengalami kenaikan nilai rata-rata sebesar 11,562. Peningkatan nilai anak dalam memahami multikultural menunjukkan bahwa media permainan MONAYA dapat diterima sebagai salah satu media untuk mengenalkan multikultural atau budaya Indoneisa kepada anak usia dini.

Selanjutnya, dalam penelitian media permainan MONAYA ini, uji efektivitas penggunaan media dihitung menggunakan uji $\mathrm{t}$ berpasangan melalui SPSS versi 16 dengan menggunakan rumus paired sample t-test yang merupakan uji dari dua sampel berpasangan. Sampel berpasangan adalah sampel yang sama tetapi mendapatkan perlakuan yang berbeda, dalam penelitian ini adalah pretest dan post-test.

Hasil analisis data t-test berpasangan yang diolah menggunakan SPSS versi 16 adalah sebagai berikut. 
dapat meningkatkan kemampuan motorik dan sosial anak. Banyak manfaat yang dapat diambil dari aktivitas bermain sehingga bermain tidak bisa dilepaskan dari anak usia dini.

Melalui bermain, seorang anak dapat belajar berbagai hal baru yang belum ia kuasai sebelumnya. Bermain sambil belajar merupakan prinsip dasar pembelajaran anak dan pembelajaran terbaik anak adalah dengan adanya perencanaan kegiatan bermain (Ciolan, 2013, hlm. 187). Permainan dapat dilakukan baik di luar maupun di dalam kelas agar pembelajaran tidak kaku,

Nilai dari hasil perhitungan t-test berpasangan atau paired test dengan menggunakan aplikasi SPSS versi 16 diperoleh hasil $t$ hitung sebesar -9.492 dengan nilai signifikansi (2-tailed) sebesar 0.000 sehingga $0.000<0.05$. Hasil dari nilai signifikansi (2-tailed) sebesar 0.000 yang lebih kecil dari 0.05 menyimpulkan bahwa media permainan MONAYA efektif digunakan untuk meningkatkan pemahaman multikultural pada anak usia 78 tahun.

Metode pengajaran yang dilakukan pada kegiatan pembelajaran sehari-hari mempengaruhi suasana hati anak ketika belajar. Dengan metode bermain dalam pembelajaran dapat menarik minat anak untuk belajar. Pada penelitian ini, metode bermain dilakukan untuk membantu anak dalam meningkatkan pemahaman terkait multikultural. Permainan MONAYA (Monopoli Budaya) hadir sebagai salah satu bentuk permainan monopoli dengan aturan permainan yang sangat unik sehingga anak tertarik untuk bermain sambil belajar. Hal ini sejalan dengan pernyataan Fadillah (2017, hlm. 7) yang mengatakan bahwa bermain merupakan kebutuhan alamiah anak usia dini. Selain sebagai aktivitas bersenang-senang, bermain juga merupakan kegiatan belajar bagi anak karena anak usia dini belajar melalui bermain. Menurut Mihaela (2013, hlm. 599), bermain merupakan suatu kebutuhan bagi anak karena anak mendapatkan pengalamannya sendiri dan monoton dan siswa tidak merasa bosan sehingga siswa cepat memahami konsep materi yang diajarkan (Syahbarina, 2017, hlm. 248). Oleh karena itu, MONAYA dapat dijadikan salah satu permainan yang sesuai untuk dimainkan agar terjadi kegiatan pembelajaran yang tidak membosankan.

Media permainan MONAYA merupakan permainan papan yang memiliki banyak manfaat untuk digunakan oleh anak. Seperti yang dikatakan Casbergue dalam Mostowfi (2016, hlm. 5457) bahwa permainan papan merupakan alat edukasi yang dapat membantu anak untuk memperoleh keterampilan, mendapatkan informasi mengenai pembelajaran, memperkuat pengetahuan dan meningkatkan kepercayaan. Selain itu, permainan papan juga dapat meningkatkan kerjasama dan solidaritas antar peserta sehingga dapat disimpulkan bahwa permainan MONAYA merupakan permainan yang tepat untuk meningkatkan suatu pemahaman pada anak usia dini.

Selain itu, media permainan MONAYA pun memiliki tampilan media visual yang menarik sehingga dapat mempengaruhi minat anak dalam proses penggunaannya. Hal ini sejalan dengan yang dikatakan oleh Umar (2013, hlm. 132) dalam penelitiannya, bahwa media dalam pembelajaran memegang peranan penting dalam kegiatan belajar mengajar karena dapat meningkatkan dan mengarahkan 
perhatian anak sehingga menimbulkan motivasi belajar. Oleh karena itu, dapat dikatakan bahwa media permainan MONAYA merupakan media yang tepat untuk meningkatkan motivasi anak dalam memperoleh pengetahuan.

Penelitian dan pengembangan ini dilakukan dengan tujuan untuk menghasilkan sebuah produk berupa media permainan MONAYA (Monopoli Budaya) yang dapat digunakan untuk meningkatkan pemahaman multikultural pada anak usia 78 tahun. Media permainan MONAYA ini memiliki satu buah papan besar yang dicetak pada banner dan produk penunjang lainnya seperti dadu dan kartu-kartu dengan ukuran besar serta buku panduan sebagai pedoman permainan. Hal ini sesuai dengan metode penelitian dan pengembangan (Research and Development) yang merupakan metode penelitian dengan tujuan untuk menghasilkan produk tertentu, dan menguji keefektifan produk tersebut. Artinya untuk dapat menghasilkan produk permainan MONAYA ini, telah melalui proses analisis kebutuhan, validasi pakar dan uji efektivitas produk tersebut agar dapat mencapai tujuan awal pembuatan produk ini.

Hasil validasi pakar diperoleh kesimpulan bahwa media permainan MONAYA layak digunakan sebagai media pembelajaran pada anak usia dini untuk meningkatkan pemahaman multikultural. Selain itu, dari hasil uji efektivitas didapatkan kesimpulan bahwa nilai t hitung sebesar -9.492 dengan nilai signifikansi (2tailed) sebesar 0.000 sehingga $0.000<0.05$. Hasil dari nilai signifikansi (2-tailed) sebesar 0.000 yang lebih kecil dari 0.05 menyimpulkan bahwa media permainan MONAYA efektif digunakan untuk meningkatkan pemahaman multikultural pada anak usia 7-8 tahun.

\section{KESIMPULAN}

Penelitian ini merupakan jenis penelitian dan pengembangan yang menggunakan metode ADDIE (Analyze, Design, Develop, Implement, Evaluate) dan menghasilkan suatu model atau produk berupa media permainan MONAYA yaitu permainan monopoli budaya yang dicetak di banner besar dengan menggunakan anak sebagai pionnya. Tujuan dari penelitian dan pengembangan media permainan MONAYA ini adalah untuk meningkatkan pemahaman multikultural pada anak usia 78 tahun. Pemahaman multikultural yang dimaksud adalah identitas individu yang terdiri dari suku, ras, agama dan jenis kelamin. Pada penelitian ini terdapat uji kelayakan melalui proses uji pakar/ahli, uji coba satu-satu (one to one), uji coba kelompok kecil (small group) dan uji coba kelompok besar (field group) sehingga didapatkan hasil bahwa media permainan MONAYA dinilai layak untuk meningkatkan pemahaman multikultural pada anak usia 7-8 tahun.

Pada uji efektivitas, didapatkan hasil bahwa media permainan MONAYA dinilai efektif untuk meningkatkan pemahaman multikultural pada anak usia 78 tahun berupa identitas individu yang mencakup suku, ras, agama dan jenis kelamin. Keefektifan media permainan MONAYA dapat dilihat melalui adanya perbedaan antara sebelum dan sesudah dilakukannya media permainan MONAYA tersebut.Terdapat kegiatan pre test dan post test yang bertujuan untuk mengetahui nilai yang diperoleh anak antara sebelum dan sesudah media permainan MONAYA dilakukan. Hasil kegiatan pre test dan post test tersebut menunjukkan nilai post test anak lebih tinggi daripada nilai pre test, sehingga dapat disimpulkan bahwa terjadi peningkatan nilai yang berarti pemahaman anak terhadap multikultural berupa identitas individu yang mencakup suku, ras, agama dan jenis kelamin meningkat setelah bermain media permainan MONAYA.

Peneliti selanjutnya diharapkan dapat melakukan penelitian-penelitian yang lebih berinovasi dan kreatif lagi baik dari segi konten maupun media atau produk yang diciptakan, terutama media terkait pengenalan keberagaman budaya Indonesia 
agar anak mengenal dan mencintai Negara Indonesia sejak dini.

\section{DAFTAR PUSTAKA}

Ananda, R., \& Fadhilaturrahmi, F. (2018). Peningkatan Kemampuan Sosial Emosional Melalui Permainan Kolaboratif pada Anak KB. Jurnal Obsesi: Jurnal Pendidikan Anak Usia Dini, 2(1), 20-26.

Branch, R. M. (2008). Instructional Design: The ADDIE Approach. Evolution.

Ciolan, L. E. (2013). Play to Learn, Learn to Play. Creating Better Opportunities for Learning in Early Childhood. Procedia - Social and Behavioral Sciences, 76, 186-189. https://doi.org/10.1016/j.sbspro.20 13.04.096

Fadillah, M. (2017). Bermain dan Permainan Anak usia Dini. Kencana (Vol. 1). https://doi.org/10.1145/2505515.25 07827

Belva, H. A., dkk. (2015). POBUNDO (Pop-Up Budaya Indonesia) Sebagai Media Pembelajaran Berbasis Kebudayaan Untuk Siswa Kelas IV Sekolah Dasar, Jurnal Pelita Vol X No, 1 pp. 65-76.

Joni. (2016). Peningkatan Kemampuan Kognitif Anak dalam Kegiatan Berhitung dengan Permainan Dadu TK Mutiara Pekanbaru. Jurnal Obsesi, 2(2005), 73-78. https://doi.org/10.1016/j.pec.2011. 10.002

Logvinova, O. K. (2016). Sociopedagogical approach to multicultural education at preschool. Procedia - Social and Behavioral Sciences.

Lucas, F. M. M. (2017). The Game as an Early Childhood Learning Resource for Intercultural Education. Procedia - Social and Behavioral Sciences, 237(June 2016), 908-913. https://doi.org/10.1016/j.sbspro.20 17.02.127
Mihaela, P. L. (2013). Play in school context. Physics Procedia. https://doi.org/10.1016/j.sbspro.20 13.04.171

Mokeyevaa, E. V., \& Andreeva, I. N. (2016). Civic and patriotic education of pre-school children. International Journal of Environmental and Science Education, 11(9), 2223-2236. https://doi.org/10.12973/ijese.2016. $600 \mathrm{a}$

Mostowfi, S., Mamaghani, N. K., \& Khorramar, M. (2016). Designing playful learning by using educational board game for children in the age range of 7-12: (A case study: Recycling and waste separation education board game). International Journal of Environmental and Science Education, 11(12), 5453-5476. https://doi.org/10.1001/archsurg.20 10.28-a

Peraturan Kemendikbud. (2014). Peraturan Menteri Pendidikan dan Kebudayaan Republik Indonesia No. 10 Tahun 2014. Protein Science, 16(4), 733-743. https://doi.org/10.1161/01.STR.32. 1.139

Soerjoatmodjo, G. W. L. (2015). Storytelling, Cultural Heritage and Public Engagement in AkhirPekan@MuseumNasional. Procedia - Social and Behavioral Sciences, 184(August 2014), 8794.

https://doi.org/10.1016/j.sbspro.20 15.05.057

Syahbarina, M. (2017). Pengembangan Media MONORAJA (Monopoli Aksara Jawa) untuk Siswa Sekolah Dasar. Mimbar Sekolah Dasar, 4(3), 245. https://doi.org/10.17509/mimbarsd.v4i3.7919

Umar. (2013). Media Pendidikan: Peran dan Fungsinya dalam Pembelajaran, 10, 126-141. 